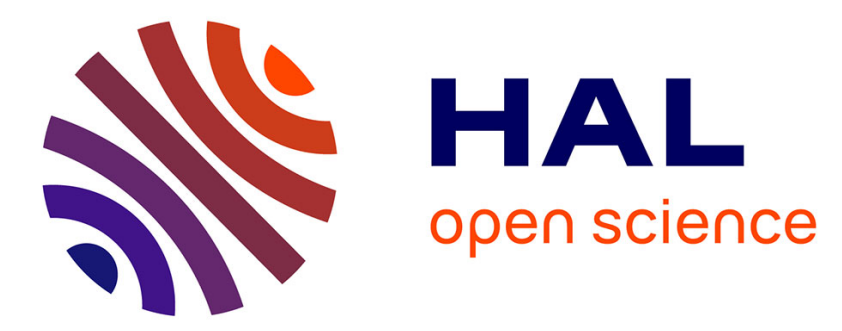

\title{
Using an Information Management Model as a Roadmap for Information Systems Implementation in Supply Networks
}

Cláudio Santos, Ana Cristina Barros, Tom Dawes, António Lucas Soares

\section{To cite this version:}

Cláudio Santos, Ana Cristina Barros, Tom Dawes, António Lucas Soares. Using an Information Management Model as a Roadmap for Information Systems Implementation in Supply Networks. 17th Working Conference on Virtual Enterprises (PRO-VE), Oct 2016, Porto, Portugal. pp.73-83, 10.1007/978-3-319-45390-3_7 . hal-01614625

\author{
HAL Id: hal-01614625 \\ https://hal.inria.fr/hal-01614625
}

Submitted on 11 Oct 2017

HAL is a multi-disciplinary open access archive for the deposit and dissemination of scientific research documents, whether they are published or not. The documents may come from teaching and research institutions in France or abroad, or from public or private research centers.
L'archive ouverte pluridisciplinaire HAL, est destinée au dépôt et à la diffusion de documents scientifiques de niveau recherche, publiés ou non, émanant des établissements d'enseignement et de recherche français ou étrangers, des laboratoires publics ou privés. 


\title{
Using an Information Management Model as a Roadmap for Information Systems Implementation in Supply Networks
}

\author{
Cláudio Santos ${ }^{1}$, Ana Cristina Barros ${ }^{1}$, Tom Dawes ${ }^{2}$ and António Lucas Soares ${ }^{1,3}$ \\ ${ }^{1}$ INESC TEC, Porto, Portugal \\ ${ }^{2}$ Valuechain.com, Sci-Tech Daresbury UK \\ ${ }^{3}$ Faculty of Engineering, University of Porto, Porto, Portugal \\ claudio.a.santos@inesctec.pt, acbarros@inesctec.pt, tdawes@valuechain.com, als@fe.up.pt
}

\begin{abstract}
In the era of information overflow, the effective implementation of models for managing multiple information streams may contribute to organizations' decision-making capabilities. Even though literature has proposed several information management models, little has been described about their implementation in real-world settings. This paper presents a case study on the usage of an information management model in the implementation of a collaborative system in a supply network. The case application analysis reinforces the value of using information management models to account for cultural aspects in the mapping of information needs and in the analysis of multiple stakeholders' requirements.
\end{abstract}

Keywords: information management model, supply networks, collaboration, case study

\section{Introduction}

The methods employed by organizations to manage their information flows has been playing a critical role in the competitiveness of their businesses. Environmental turbulence requires that organizations have access to accurate information in real time in order to respond quickly to changes. Furthermore, and particularly observed in a number of sectors, organizations are focusing on their core competencies and thus, start establishing collaborations with partners to search for complementary resources and capabilities, this being an emerging paradigm for competitiveness of some industrial sectors [1].

Existing information management models in the literature describe the process by which information is managed by organizations internally and with other organizations, with little exploration of the implications about implementation of these models in particular organizational networks. This article aims at demonstrating, by means of a single case study, the importance of using an information management model during the implementation of information systems in supply networks. 
This article is organized as follows: section 2 reviews the literature on information systems and information management models, section 3 describes the research methodology used in this study, section 4 introduces a brief characterization of the case under study, section 5 analyses the case application and, finally, section 6 presents the discussion.

\section{Literature Review}

\subsection{Information systems}

Information systems involve people, knowledge, organization and information technology that, by implementing an information management model, allow supply networks to collect, analyze, and disseminate information in order to improve decision making [2]. Information systems enable real-time communication between all partners within a supply network regardless their location and enable improving the quality of the information shared [2], [3], [4], [5]. Table 1 provides an overview of research about information systems for supply networks.

Table 1. Information systems for supply networks

\begin{tabular}{|c|c|c|c|}
\hline $\begin{array}{l}\text { Information } \\
\text { System }\end{array}$ & Description & Benefits & References \\
\hline $\begin{array}{l}\text { Data warehouses } \\
\text { (DW) }\end{array}$ & $\begin{array}{l}\text { Combination of } \\
\text { databases for the } \\
\text { network relationships }\end{array}$ & $\begin{array}{l}\text { Enables data integration and } \\
\text { effective information } \\
\text { management in a single system; } \\
\text { lower costs in supply network } \\
\text { integration; supports partners' } \\
\text { relationships }\end{array}$ & [5] \\
\hline $\begin{array}{l}\text { Electronic Data } \\
\text { Interchange } \\
\text { (EDI) }\end{array}$ & $\begin{array}{l}\text { Acquire the accurate } \\
\text { information flow when } \\
\text { information on } \\
\text { electronic format is } \\
\text { shared through } \\
\text { different network } \\
\text { computers }\end{array}$ & $\begin{array}{l}\text { Improvement of information } \\
\text { quality and operational } \\
\text { efficiency; reduction of } \\
\text { transaction cost }\end{array}$ & $\begin{array}{c}\text { [4], [5], [6], } \\
{[7]}\end{array}$ \\
\hline $\begin{array}{c}\text { Enterprise } \\
\text { Resource } \\
\text { Planning (ERP) } \\
\text { system }\end{array}$ & $\begin{array}{l}\text { Efficient information } \\
\text { system for a better } \\
\text { integration of } \\
\text { information and } \\
\text { knowledge }\end{array}$ & $\begin{array}{l}\text { Support information flow; } \\
\text { information is entered } \\
\text { immediately when changed, } \\
\text { allowing the transfer of the } \\
\text { changes to all partners; } \\
\text { sharpest vision for supply } \\
\text { network management }\end{array}$ & [8] \\
\hline $\begin{array}{l}\text { Knowledge } \\
\text { management } \\
\text { platforms }\end{array}$ & $\begin{array}{l}\text { Management of all } \\
\text { available information } \\
\text { and knowledge in one } \\
\text { distributed knowledge } \\
\text { base }\end{array}$ & $\begin{array}{l}\text { Provides access to internal } \\
\text { information models of supply } \\
\text { network partners based on their } \\
\text { competence profiles }\end{array}$ & [9] \\
\hline
\end{tabular}


Information Management Model as a Roadmap for IS Implementation

\begin{tabular}{|c|c|c|c|}
\hline $\begin{array}{c}\text { Information } \\
\text { System }\end{array}$ & Description & Benefits & References \\
\hline $\begin{array}{c}\text { Product } \\
\text { Lifecycle } \\
\text { Management } \\
\text { (PLM) system }\end{array}$ & $\begin{array}{l}\text { Provide product } \\
\text { information to several } \\
\text { regional ERP system } \\
\text { and a global } \\
\text { application systems }\end{array}$ & $\begin{array}{l}\text { Information directly introduced } \\
\text { into the receiving systems }\end{array}$ & [10] \\
\hline $\begin{array}{c}\text { Project } \\
\text { Integrated } \\
\text { Databases (PIDs) }\end{array}$ & $\begin{array}{l}\text { Systematic } \\
\text { infrastructure for } \\
\text { project information } \\
\text { sharing across supply } \\
\text { network }\end{array}$ & $\begin{array}{l}\text { Allows the sharing of project } \\
\text { information to the network } \\
\text { partners through a } \\
\text { shared conceptual } \\
\text { product/process model }\end{array}$ & [11] \\
\hline $\begin{array}{l}\text { Radio Frequency } \\
\text { Identification } \\
\text { (RFID) based } \\
\text { information } \\
\text { systems }\end{array}$ & $\begin{array}{l}\text { Automatic } \\
\text { identification } \\
\text { technology that uses } \\
\text { smart labels in order to } \\
\text { trace products through } \\
\text { the supply network and } \\
\text { trace quality } \\
\text { information }\end{array}$ & $\begin{array}{l}\text { Product information stored in the } \\
\text { tag ship; eliminate the delay of } \\
\text { information sharing; information } \\
\text { is gathered } \\
\text { and stored into the product } \\
\text { throughout its life cycle }\end{array}$ & $\begin{array}{c}{[5],[6],} \\
{[12],} \\
{[13],[14]}\end{array}$ \\
\hline $\begin{array}{l}\text { Web-centric } \\
\text { Extended } \\
\text { Enterprise } \\
\text { Knowledge } \\
\text { Sharing } \\
\text { (WEEKS) } \\
\text { system }\end{array}$ & $\begin{array}{l}\text { Intends to enhance } \\
\text { performance of the } \\
\text { supply network } \\
\text { through the sharing of } \\
\text { knowledge } \\
\text { electronically }\end{array}$ & $\begin{array}{l}\text { Assists the decision making, } \\
\text { provides to managers alternatives } \\
\text { to a problem after receiving } \\
\text { pertinent information, provides a } \\
\text { structured framework to aid the } \\
\text { development of knowledge } \\
\text { management }\end{array}$ & [15] \\
\hline $\begin{array}{l}\text { Web- } \\
\text { Collaborative } \\
\text { Extranets } \\
\text { (WCEs) }\end{array}$ & $\begin{array}{l}\text { Electronic } \\
\text { management systems } \\
\text { which in a secure and } \\
\text { private network uses } \\
\text { web protocols to share } \\
\text { information }\end{array}$ & $\begin{array}{l}\text { Cost efficiency, time efficiency, } \\
\text { communication improvement, } \\
\text { trust and transparency, } \\
\text { knowledge base and learning } \\
\text { organization }\end{array}$ & [11] \\
\hline
\end{tabular}

Table 1 shows the variety of systems that exist for accurate sharing of information among organizations. Effective information sharing is possible when the required information systems are implemented, providing accurate information to supply network partners that supports effective decision making [3], [5]. Still, the implementation of information systems alone will not be sufficient to improve the collaboration in supply networks. In fact, in order to develop information sharing capabilities companies have to work in parallel on the connectivity of information systems, on the willingness of companies to share information and on the capability of supply network partners to manage information effectively [2], [16].

\subsection{Information Management Model}

Information management is the management of the processes and systems that create, acquire, organize, store, distribute, and use information [17]. Thus, information management helps people and organizations access, process and use information 
efficiently and effectively. Organizations with information management capability are able to provide data and information to users with the appropriate levels of accuracy, timeliness, reliability, security, confidentiality, connectivity, and access [18]. Towards this goal, companies develop and implement information management models following a number of steps. Table 2 synthesizes the stages of information management models found in the literature. The first column presents the stages of information management models and is followed by its description, which is based on the references mentioning it as identified in the last four columns of the table.

Table 2. Stages of information management models

\begin{tabular}{|c|c|c|c|c|c|}
\hline Stages & Description & [19] & {$[16]$} & {$[20]$} & [17] \\
\hline $\begin{array}{l}\text { Identifying } \\
\text { needs }\end{array}$ & $\begin{array}{l}\text { Identifying what and why information is needed, how it is } \\
\text { going to be used, and the attributes that will enhance its } \\
\text { value, quality, and usefulness. }\end{array}$ & $\mathrm{X}$ & & $X$ & \\
\hline Sensing & $\begin{array}{l}\text { Detecting and identifying information concerning: } \\
\text { economic, social and political changes; competitors' } \\
\text { innovations that might impact the business; market shifts } \\
\text { and customer demands for new products: anticipated } \\
\text { problems with suppliers and partners. }\end{array}$ & & $\mathrm{X}$ & & \\
\hline Creating & Generating and producing new information. & & & & $\mathrm{X}$ \\
\hline Gathering & $\begin{array}{l}\text { Collecting relevant information from internal and external } \\
\text { sources. }\end{array}$ & $\mathrm{X}$ & $X$ & $\mathrm{X}$ & $\mathrm{X}$ \\
\hline Organizing & $\begin{array}{l}\text { Indexing, classifying, and linking information to support } \\
\text { its retrieval when it is needed. }\end{array}$ & & $\mathrm{X}$ & $\mathrm{X}$ & $\mathrm{X}$ \\
\hline $\begin{array}{l}\text { Storing and } \\
\text { maintaining }\end{array}$ & $\begin{array}{l}\text { Physically housing the information in databases or file } \\
\text { systems in order to avoid the repeated collection of } \\
\text { information and updating it to ensure that the best } \\
\text { information available is used. }\end{array}$ & & $\mathrm{X}$ & $\mathrm{X}$ & $\mathrm{X}$ \\
\hline Processing & $\begin{array}{l}\text { Accessing, analysing, and presenting the information in a } \\
\text { way that supports decision making. }\end{array}$ & & $X$ & $\mathrm{X}$ & \\
\hline Sharing & $\begin{array}{l}\text { Distributing or disseminating to the adequate users } \\
\text { according to the information needs. }\end{array}$ & $X$ & & $X$ & $\mathrm{X}$ \\
\hline Using & $\begin{array}{l}\text { Applying the information made available for better } \\
\text { decision-making. }\end{array}$ & $\mathrm{X}$ & & $\mathrm{X}$ & $\mathrm{X}$ \\
\hline
\end{tabular}

\section{Research Methodology}

This paper reports a case study about the implementation of a collaborative system in a multi-tiered supply network. Insights from this implementation are discussed through the lens of the information management model framework introduced in section 2.2.

Data was collected through a structured interview with the manager of the company in charge of the development and implementation of the system. Secondary data was 
collected from company reports and presentations. A brief overview of the company is presented in the next section.

\section{Company Characterization}

This study reports a UK-based information and communication technology (ICT) company engaged in the development of collaborative platforms for multi-tiered supply networks. The company has a wide range of solutions dedicated to promote the sharing of strategic, tactical and operational data between network members to support collaborative work and performance improvements.

The company develops solutions for SMEs, large Primes and Tiers 1, raw materials suppliers and industrial associations. These solutions support visibility and transparency among supply networks in several ways: 1) through the streamlining of operations, 2) the real-time monitoring of risks in the network, 3) the mapping of members' capabilities and 4) through collaborative platforms to support new product introduction, work package management, logistics, etc. In terms of operations, collaboration potentiated by the ICT company's solutions enable customers' relationship management, supply chain management, collaborative inventory management, aggregated procurement, collaborative tendering and collaborative project management. This system could be added to the information systems already reported in the literature and listed in Table 1. For a better understanding of the information systems in study, Figures 1, 2 and 3 provide a snapshot of some of the functionalities embedded in ICT company's solutions.

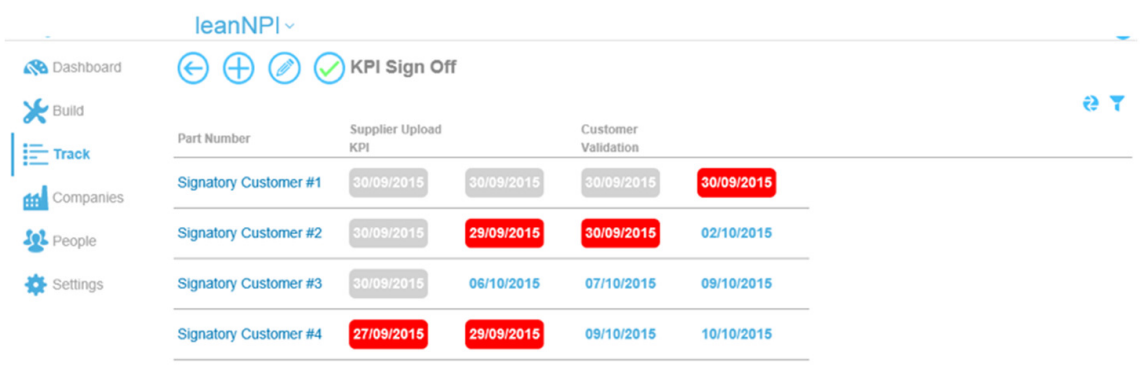

Figure 1 - Display of collaborative project management features for new product introduction (NPI) 


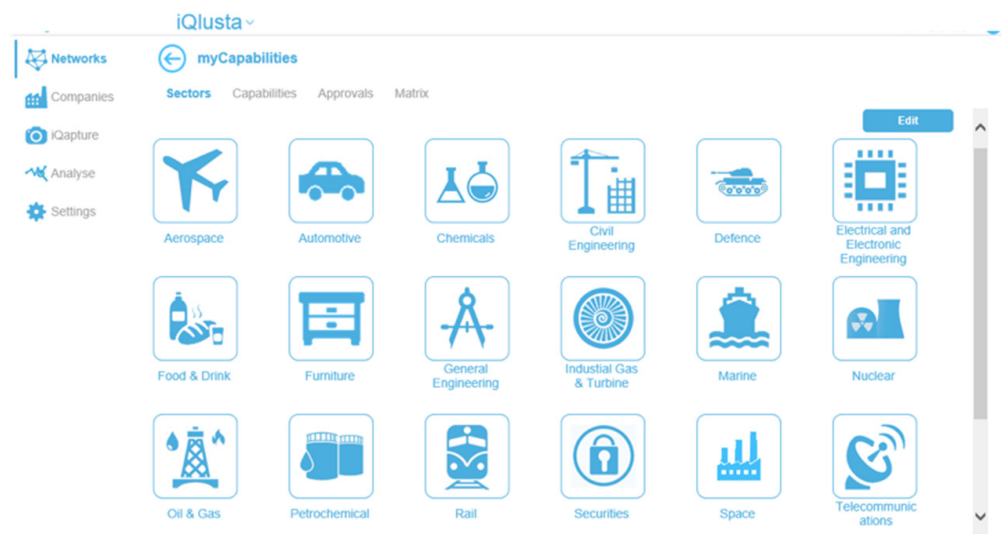

Figure 2 - Display of capabilities mapping features

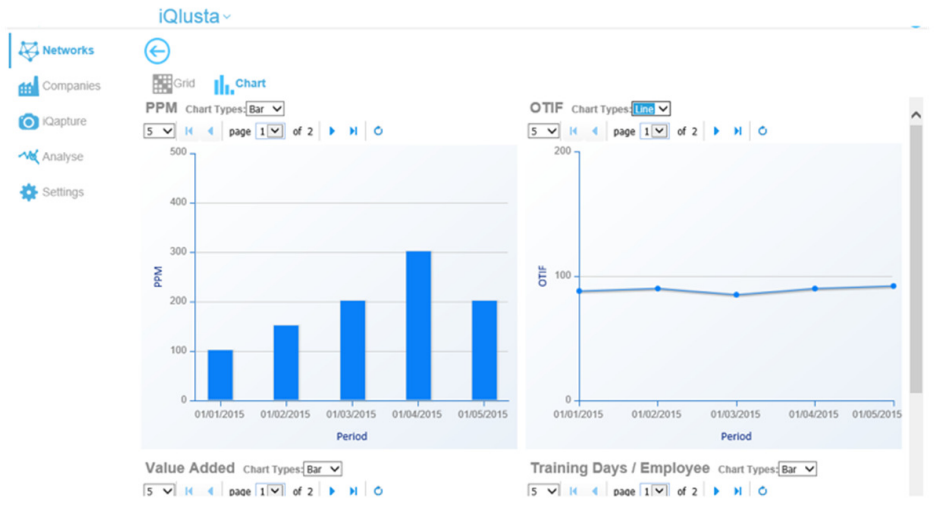

Figure 3 - Display of performance monitoring features

\section{Case Application}

This section demonstrates that the information management model proposed in section 2.2 can be used as a roadmap for information systems implementation in supply networks by describing the implementation of a collaborative system in a supply network in the UK. The case application refers to a national-level program promoted by a large trade organization, aimed to improve the competitiveness and performance of the supply chain of a particular UK industrial sector. This program supports several initiatives and projects with close interaction with small to large businesses. The following text describes the implementation, by the company, of a collaborative system in this network.

The objective of the implemented collaborative system is to promote, through a portal, the secure sharing of data between network members to ultimately support the 
development of network intelligence. The project had five stakeholders: the trade organization, regional alliances, training providers, suppliers of parts and components and customers. The trade organization is the main promoter of the project.

Addressing multiple, and sometimes conflicting, stakeholders' requirements was one of the key challenges of the project. Companies in different tiers of the supply chain have different business objectives. On a systems perspective, these companies present disparate system infrastructure, maturity and capabilities. Despite these challenges, the unifying objective is embodied in the mission of the main promoter of the project improve overall supply network performance. This, according to the perspective of the trade organization, was possible by stimulating collaborative working methods in supply networks.

Contrary to a typical top-down and autocratic approach where suppliers have to conform to a system that is being pushed by a large organization, this project envisioned a collaborative system where all stakeholders voluntarily participate. As important as mapping information requirements, the cultural aspect, meaning how to engage people and align objectives, was critical.

After a period of mapping business processes, communication and information flows, organization by organization, workshops with groups of stakeholders were held to present the proposed set of features, the proof of concept and the expected benefits for each stakeholder group. This provided the basis for scoping the requirements that meet the expectations of every stakeholders' group.

The requirements were broken down into a mock-up of the features of the system. The refinement of requirements and functionalities was an iterative process, as data availability was largely dependent on the engagement level of stakeholders. The system was initially fed with data readily available from the trade organization concerning basic information such as members name, address, contacts, etc., which was then validated by the members.

Participation in the virtual network initiates by creating a passive network. A passive network is created by introducing basic network members' data into the information system in order to facilitate network members' enrolment in the future. The conversion of a passive network into an active network, where members are invited to connect, collaborate and share data, is the next step. Different types of data are maintained by different stakeholders: auditing data, for example, is generated by suppliers and training providers, but maintained by OEMs and Tiers 1 (the customers). Performance data is also generated by suppliers, and verified and validated by their customers. Financial and quality approvals data is generated by third party systems (e.g. credit checking systems and regulatory agencies), but companies are also able to complement with more detailed information. The system is currently not able to gather data from other third party systems, such as data concerning potential socio-economical risks in the supply chain.

Data is organized into six areas: basic information (contacts, addresses, documents, etc.), capabilities (technical and manufacturing capabilities, quality approvals, plant lists, etc.), collaboration (activities, projects, business opportunities, e-mail integration, etc.), auditing, performance and finance (credit check and accounts management). Data is stored in a third party cloud host, and its integrity is verified through an automated exception monitoring system. 
Information processing supports collaboration between network members. The sharing permissions depends on data ownership, which is split between four parties: public (data that can be found in other sources, such as the internet); companies; network leader, which in this case application is the trade organization, and third party systems. Data owners decide which data they want to share and with whom. Table 3 presents a summary of the information management model stages from the case analysed above.

Table 3 - Information management model stages from the case study

\begin{tabular}{cl}
\hline Stages & \multicolumn{1}{c}{ Implemented approach } \\
\hline & - multiple stakeholders' requirements analysis; \\
& - different objectives and systems' maturity and infrastructures; \\
Identifying & - need to understand cultural aspects from organizations; \\
information & - individual interviews: data, communications and business processes \\
needs & mapping; \\
& - workshops with stakeholders' groups to present envisioned benefits and \\
& proof-of-concepts.
\end{tabular}

Observing Table 1, the described collaborative system could be categorized as a Web-Collaborative Extranet, such is the emphasis put in building secure private networks to share information. However, features of Knowledge Management and Web-centric Extended Enterprise Knowledge sharing platforms can also be pointed out. This suggests a mixed-approach in the design of the information system that is embedded in the collaborative platform.

This collaborative system is in its pilot stage, however, it has been implemented in a network of approximately seven hundred suppliers, fifteen OEMs and Tiers 1, six regional alliances and eight training providers. By considering multiple stakeholders' requirements and organizational cultures, the envisioned benefits from the implementation of the collaborative platform include network intelligence and visibility of business opportunities. 


\section{Discussion}

The case application analysis highlighted the importance of the organizational change needed to support the implementation of a collaborative system. Despite having a governance entity - the trade organization - the implementation of the collaborative system did not follow the typical top-down approach, where requirements are pushed down from a large organization. It was extremely dependent on members' voluntary participation and data inputs and, as such, understanding cultural aspects of organizations was important to engage them into the system.

The intention of this case study was not the analysis of a technical solution, simply mapping information flows and stakeholders' requirements, but rather on the insights about using information management models in the implementation of information systems in a multi-tiered supply network. Thus, information management models should put more emphasis in the understanding of multiple stakeholders' objectives and in benefits realization to promote a more effective implementation. The approach followed by the organization implementing the collaborative platform involved features from multiple information systems paradigms.

The empirical evidence collected in this research showed a number of benefits of using the information management model as a tool for the implementation of information systems in supply networks. The information model potentiates an ecosystem of intelligence, productivity and collaboration among supply chain partners at all tiers of the supply chain. The information model simplifies the capture, consolidation and analysis of multiple datasets from supply chain partners and allows for the creation of highly customisable user interfaces to meet diverse stakeholder requirements. By simplifying supply chain descriptive analytics, key stakeholders are able to redeploy data capture and focus on diagnostic analytics to identify root causes of supply chain risks and performance issues which will provide valuable insight for predictive and prescriptive supply chain analytics.

This study reports a single case study, which is a limitation for generalization. Future research should focus on extending the analysis to other implementations and consider literature on technology adoption to deepen our knowledge about information management models.

\section{Acknowledgements}

This work was funded by the Project CMUP-ERI/TPE/0011/2013 of the CMU Portugal Program, financed by the Fundação para a Ciência e a Tecnologia (Portuguese Foundation for Science and Technology), and by the Project "NORTE-07-0124FEDER-000057", financed by the North Portugal Regional Operational Programme (ON.2 - O Novo Norte), under the NSRF, through the European Regional Development Fund, and by national funds, through the Portuguese funding agency, Fundação para a Ciência e a Tecnologia. 


\section{References}

1. Durugbo, C., Erkoyuncu, J. a.: Managing Integrated Information Flow for Industrial Service Partnerships: A Case Study of Aerospace Firms. Procedia CIRP. 16, 338-343 (2014).

2. Fawcett, S.E., Osterhaus, P., Magnan, G.M., Brau, J.C., McCarter, M.W.: Information sharing and supply chain performance: the role of connectivity and willingness. Supply Chain Manag. An Int. J. 12, 358-368 (2007).

3. Baihaqi, I., Sohal, A.S.: The impact of information sharing in supply chains on organisational performance: An empirical study. Prod. Plan. Control. 24, 743-758 (2013).

4. Li, S., Lin, B.: Accessing information sharing and information quality in supply chain management. Decis. Support Syst. 42, 1641-1656 (2006).

5. Omar, R., Ramayah, T., Lo, M.-C., Sang, T.Y., Siron, R.: Information sharing, information quality and usage of information technology (IT) tools in Malaysian organizations. African J. Bus. Manag. 4, 2486-2499 (2010).

6. Legner, C., Schemm, J.: Toward the Inter-organizational Product Information Supply Chain -- Evidence from the Retail and Consumer Goods Industries. J. Assoc. Inf. Syst. 9, 119-150 (2008).

7. Wilson, T.D.: Information sharing: an exploration of the literature and some propositions. Inf. Res. - An Int. Electron. J. 15, (2010).

8. Toloie-Eshlaghi, A., Asadollahi, A., Poorebrahimi, A.: The role of Enterprise Resources Planning (ERP) in the contribution and integration of the information in the supply chain. Eur. J. Soc. Sci. 20, 16-27 (2011).

9. Smirnov, A., Shilov, N., Kashevnik, A.: Developing a knowledge management platform for automotive build-to-order production network. Hum. Syst. Manag. 27, 15-30 (2008).

10. Hüner, K.M., Schierning, A., Otto, B., Österle, H.: Product data quality in supply chains: The case of beiersdorf. Electron. Mark. 21, 141-154 (2011).

11. Ajam, M., Alshawi, M., Mezher, T.: Augmented process model for e-tendering: Towards integrating object models with document management systems. Autom. Constr. 19, 762-778 (2010).

12. Bindel, A., Rosamond, E., Conway, P., West, A.: Product life cycle information management in the electronics supply chain. Proc. Inst. Mech. Eng. Part B - J. Eng. Manuf. 226, 13881400 (2012).

13. Bottani, E., Bertolini, M., Montanari, R., Volpi, A.: RFID-enabled business intelligence modules for supply chain optimisation. Int. J. RF Technol. Res. Appl. 1, 253-278 (2009).

14. Xu, L. Da: Information architecture for supply chain quality management. Int. J. Prod. Res. 49, 183-198 (2011).

15. Shih, S.C., Hsu, S.H.Y., Zhu, Z., Balasubramanian, S.K.: Knowledge sharing-A key role in the downstream supply chain. Inf. Manag. 49, 70-80 (2012).

16. Marchand, D. a, Kettinger, W.J., Rollins, J.D.: Information orientation: People, technology and the bottom line. Sloan Manage. Rev. 41, 69-80 (2000).

17. Detlor, B.: Information management. Int. J. Inf. Manage. 30, 103-108 (2010).

18. Mithas, S., Ramasubbu, N., Sambamurthy, V.: How Information Management Capability Influences Firm Performance. MIS Q. 35, 137-A15 (2011).

19. Davenport, T.H., Prusak, L.: Information Ecology: Mastering the Information and Knowledge Environment. Oxford University Press, Inc., Oxford, UK (1997).

20. Choo, C.W.: Information management for the intelligent organization: The art of environmental scanning. (2002). 